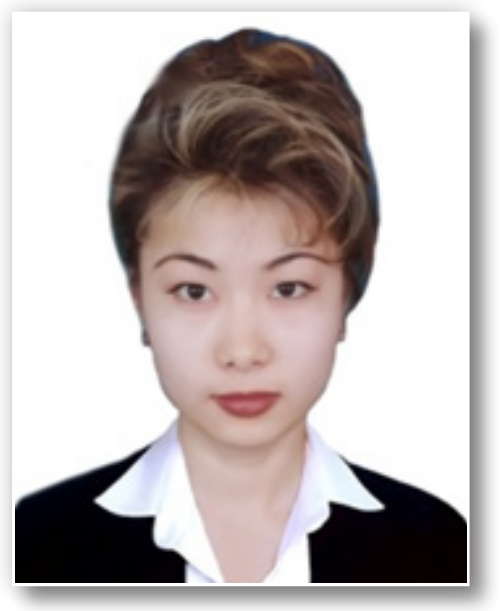

Iryna Panferova, $\mathrm{PhD}$ of Education Science, Associate Professor, Tashkent State Pedagogical University named after Nizami, Tashkent, Uzbekistan

ORCID: https://orcid.org/0000-0003-0042-1270

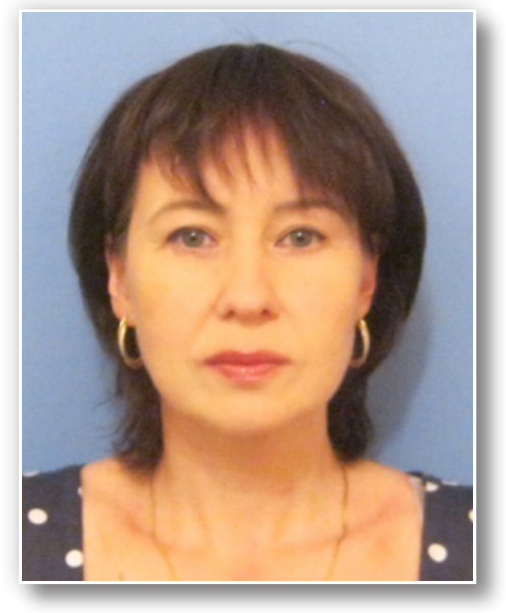

\section{Liudmyla Tomchani,}

Senior Lecturer

Turin Polytechnic University of Tashkent, Tashkent, Uzbekistan

УДК 37.013.32

DOI: https://doi.org/10.32405/2309-3935-2020-1(77)-54-58

\title{
THE COMPETENCE INTEGRATION OF LANGUAGE PROFICIENCY IN FOREIGN LANGUAGES TEACHING PROCESS
}

\section{Summary.}

The increase of language proficiency quality requirements of higher educational institutions' graduates determines the integration of new technologies and the world practice experience in teaching foreign languages. Thus, this article considers some actual issues within the framework of language competence and proficiency. First of all, we have tried to define the Uzbek education model integration in accordance with the National test level system of Language Assessment and the qualification requirements' characteristics for foreign language proficiency. To achieve the ultimate goal of language learning and acquisition it is necessary to characterize the content of competences'various types formed in the language classes. Therefore, we have posed the main aspects of communicative competence, linguistic competence, sociolinguistic competence and we have also proposed to consider intercultural competence, compensatory competence, and discursive competence. However, there has been a need for rethinking the structure and the content of professionally-oriented foreign language competence, as the role and possibility of language teaching in the professional qualities'formation of a specialist in the specific context of his professional activities have not been fully disclosed. From this point of view higher educational institution graduate's professional competence should include additional components related to professional areas and appropriate genres and interaction modes. Thus, the modern trend in obtaining language proficiency for professional development aims requires a radical change in the componential structure of professionally-oriented foreign language competence and instructional materials' modification in the process of teaching foreign languages.

Key words: integration; language proficiency; educational standards; competences.

The rapid development of the education systems and related processes, development and introduction ofnew technologies into the world practice, integration of the Uzbek model of education according to the Bologna Declaration into the European educational space determine the increase of the requirements for the quality of language proficiency of graduates of higher educational institutions.

First of all, it is necessary to consider the requirements for a specialist and identify the tasks that a graduate solves in his/her professional activity. In other words, we will try to create a professional portrait of a specialist within the framework of language competence.

The term "portrait of a specialist" is interpreted in different ways: in some cases, it refers to the characteristics of typical tasks, in other cases it is a list of activities, and thirdly - the totality of professional knowledge, skills and abilities. We can produce the professional portrait of a specialist 
based on the State Educational Standards (SES) [1], Common European Framework of Reference (CEFR) and other regulatory educational documents.
In Uzbekistan, in accordance with the National test level system of Language Assessment [2] the use of the CEFR is implemented as follows (Table 1).

The national test level system of language assessment

\begin{tabular}{|c|l|l|}
\hline \multicolumn{2}{|c|}{ Level } & \multicolumn{2}{c|}{ Level of Uzbek educational system } \\
\hline Proficient User & C 1 & Philological higher education, Master's Degree, Doctorate Degree \\
\hline Independent User & B 2 & Higher education \\
\cline { 2 - 3 } & B 1+ & Language academic lyceum \\
\cline { 2 - 3 } & B 1 & Academic lyceum and professional college \\
\hline \multirow{3}{*}{ Basic User } & A 2+ & Special language secondary school \\
\cline { 2 - 3 } & A 2 & Secondary school \\
\cline { 2 - 3 } & A 1+ & Special language elementary school \\
\cline { 2 - 3 } & A 1 & Elementary school \\
\hline
\end{tabular}

Table 1

So, in the State Educational Standard to FLT the undergraduates of the non-linguistic institutions must achieve B2 level of language proficiency.

At the same time, the requirements for the level of competences are described in the State Education Standards in general terms and are not reflected in the qualification requirements for foreign language proficiency. In our opinion, the requirements need some additions, namely: graduates should be able to communicate fully with business partners on professional and general cultural topics, negotiate, make reports, carry out international projects, banking and stock exchange operations, work with foreign economic documentation and business correspondence, critically analyze the economic literature, research business technologies and proposals coming to them, carry out oral and written translation from a foreign language into their native and from native into a foreign one.

To achieve the ultimate goal of language learning and acquisition is necessary to characterize the content of various types of competences formed in the language classes at non-language universities.

Communicative competence is the ability of a learnt language to perform speech activity in accordance with the goals and situation of communication within the particular field of activity [3]. It is based on a complex of skills that allow to participate in professional communication in its productive and receptive forms. The communicative competence is also based on a number of other competences.

Linguistic competence is grasping knowledge of a language system, rules of functioning of language units in speech, and the ability to understand other people's thoughts and express own opinion and points of view in oral and written form using this system. It supposes mastering a certain amount of formal linguistic knowledge and corresponding skills associated with various aspects of a language vocabulary, phonetics, grammar. This raises the question of what terms, grammatical structures, intones are necessary for a person of a particular age, profession, etc., to ensure professionally-oriented interaction in the target language [4]. In this regard it is interesting to compare the language contents offered in the domestic and international textbooks in the context of studying various topics and situations. Certainly, terms, grammatical constructions, intones, etc. are studied for the purpose of transforming them into meaningful statements, i.e. they have a pronounced verbal and professional orientation. Thus, it can be said that the emphasis of teaching is made not on a language as a system, but on speech. However, speech is always situational, and, the situation, in turn, is determined by the place and time, characteristics of the audience - partners in communication, purpose of communication, etc. To adequately solve the problems of communication in each specific case, in addition to linguistic competence, we need sociolinguistic competence.

Sociolinguistic (language activity) competence means knowledge of the ways of forming and formulating thoughts with the help of a language that provide the opportunity to organize and implement a speech action (to realize a communicative intention), and also the ability to use such methods to understand other people's thoughts and express their own judgments [5]. It also means the ability to use a language in a speech act. This type of competence is also called by some researchers a sociolinguistic type, trying to emphasize the ability inherent in the holder of such a competence to choose a necessary linguistic form and mode of expression, depending on the conditions of a speech act: situation, communicative goals and intentions of a speaker. To learn this, it is important for a trainee to know the semantic features of words and expressions, their change depending on a style and nature of communication, the effect that they can have on an interlocutor.

Summarizing all of what has been said, we conclude that sociolinguistic competence and the issues of verbal and linguistic admissibility have much in common. The question arises as to when 
can the formation of this competence begin? First of all, it starts at the stage of selection of linguistic and speech material, but this, as a rule, is the responsibility of the authors of textbooks. When teaching phonetics, vocabulary, grammar in a communicative context, a teacher will certainly have more than one opportunity to take into account and form the sociolinguistic experience of the trainees, provided that the teacher has this competence himself/ herself. The analysis of any authentic material gives a lot of examples, valuable in practical as well as in developing and educational aspects. Language reflects the characteristics of people's lives. Studying the diversity of expression plans, one can understand and learn a lot about the culture of different countries of the language being studied. All this leads us to the necessity of forming intercultural competence.

Intercultural competence is a tool for educating an internationally oriented person who is aware of the interdependence and integrity of the world, the need for intercultural cooperation in solving global problems of mankind. Just like sociolinguistic competence, it permeates the whole process of learning a foreign language. Let us give some examples. We all know the words denoting colors: blue, black, white, yellow, etc. Such nouns as "pages", "collar", "market", "lies", etc. are also often used. However, if in the lecture the students are asked to compose word combinations which are the most popular and meaningful in the culturological aspect, then with the word "pages" the majority would call the word "white" (white), and what is meant by the expression "yellow pages" (Yellow pages), it implies advertising directories compiled on the list of types of household services provided, unknown to many people at all. Approximately the same picture would be with the expressions "white/blue collars". The phrase "I am going to the drugstore to buy a pen" does not seem strange to anyone who knows that in America you can buy not only medicines, but also postal and writing supplies, chocolate, etc. in the pharmacy. Knowledge of background, nonequivalent vocabulary is necessary not only for translators, but for all those who want to reach the level of an independent or competent user in a foreign language. This will help to avoid misunderstandings at the level of interpersonal communication, often due to ignorance of socio-cultural characteristics.

Thus, intercultural competence implies students' knowledge of the national and cultural features of social and speech behavior of the native speakers: their customs, etiquette, social stereotypes, history and culture, as well as the ways to use this knowledge in the process of communication. The formation of such competence in ESP classes is carried out in the context of a dialogue of cultures, taking into account differences in the sociocultural perception of the world and ultimately contributes to achievement formation of a "secondary linguistic personality" for occupational purpose.

Social competence manifests itself in desire and ability to enter into communication with other people, in the ability to orientate in the situation of professional communication and build statements in accordance with the communicative intent of a speaker and the situation. This kind of competence is also called pragmatic competence, the aim of which is to emphasize the ability of a speaker to choose the most effective way of expressing thoughts depending on the conditions of a communicative act and goal [6]. It is very important here to create a sense of tolerance or, in other words, a sense of willingness to listen and understand a point of view that is different from yours. Here the principle "Who is not with us, that is against us" does not work, but may harm.

Compensatory competence is the competence using which a student can fill gaps in mastery of a language, as well as verbal and social experience of communication in the foreign environment. Possession of it enables to:

- while reading: a) anticipate the content of a text by its name, genre, table of contents in the book; b) guess the meaning of unfamiliar words, relying on the context, theme, situation; c) while referring to the dictionary, choose a correct meaning of a desired word; d) guess the meaning of an unfamiliar word from the familiar elements of its structure (root, suffix, etc.) [7];

- while listening: a) guess the meaning of a word, phrase, relying on the context; $b$ ) during interpersonal contact, address a partner for help (for example, ask to repeat what has been said) [8];

- while speaking: a) simplify a phrase, relying on known words, patterns of speech and structure of its construction; b) make corrections in own speech using expressions like "Ok, I'll express it otherwise", etc. [9].

Discursive competence (from the French discours - speech) means a student's ability to use certain strategies for constructing and interpreting a text. The concept of discourse means coherent text, a super-phrasal unity. The difference between a text and discourse is as follows: if the text is understood as an abstract-formal construction, then under discourse the texts generated as a result of communication are understood [10]. Consequently, discourse is such a speech product, which along with linguistic characteristics has extra linguistic parameters, reflecting the situation of communication and characteristics of participants in communication. Discursive competence is the knowledge of the features inherent in different types of discourses, as well as ability to generate discourses in the process of communication. The most common types of discourses in the educational and professional sphere of communication are a report, message, discussion, an inquiry, etc. [11]. 
Subject competence is the ability to orient in the content framework of professional communication in the certain sphere of professional activity, in our case, in economics.

Professional competence acquired in the course of university studies is extremely important. It provides the ability for successful professional activity and includes: a) knowledge in the field of economics, politics, statistics, and other sciences relevant to professional activities; b) skills to organize analytical and project activities and manage processes of professional activities; c) communicative skills, foreign language skills (professional terms and concepts in English); d) personal qualities that ensure the effectiveness of professional work (responsibility, politeness, exactingness, etc.).

However, there has been a need for rethinking the structure and content of professionally-oriented foreign language competence, as the role and possibility of language teaching in the formation of professional qualities of a specialist in the specific context of his professional activities have not been fully disclosed.

Thus, the modern trend in obtaining language proficiency for professional development aims requires a radical change in the componential structure of professionally-oriented foreign language competence and modification of instructional materials for foreign language departments. In this view professional competence of a graduate of the higher educational institution should include additional components related to professional areas and appropriate genres and interaction modes. Teaching and learning process should be oriented toward the profile of the specialty on the basis of the competence-based approach aimed at enabling students to independently solve cognitive, communicative, organizational, and professional issues.

\section{Використі літературні джерела}

1. Государственные Образовательные Стандарты Высшего Образования: постановление Кабинета Министров Республики Узбекистан от 10 янв. 2015 г. № 3. СЗ РУ, 2015 г., № 2, ст. 21.

2. Положение о порядке определения уровня знания иностранного языка и выдачи квалификационного сертификата: постановление Кабинета Министров Республики Узбекистан от 31 декаб. 2013 г. № 352 (Приложение № 1).

3. Savignon S.J. Communicative competence: Theory and Classroom Practice, 1997. 288 p.

4. Panferova I.V. Specific Peculiarities of Practical Teaching English Grammar at Non-Language University. European journal of education and applied psychology. Austria : EastWest, 2015. No. 2. P. 58-63.

5. Рискулова К. Система формирования социолингвистической компетенции будущих учителей английского языка: дис. ... док. пед. наук. Ташкент : УзГУМЯ, 2017. 260 с.
6. Дмитриенко Н.А. Формирование компетентного специалиста в процессе обучения иноязычному общению. Молодой ученый. 2012. № 1. Т. 2. С. 83-85.

7. Morrow K., Schoker M. Using Texts in a Communicative Approach. ELT Journal. 1987. Vol. 41, № 4. P. 248-256.

8. Jacob G. Extensive Reading and Listening in the L2 Classroom. URL: http://www.academia.edu.

9. Moiran $S$. Enseigner a comminiquer en langue etrangere. Paris, 1990. 188 p.

10. Flowerdew L. Corpus-based Analysis in EAP: Academic Discourse. London : Longman, 2002. P. 95-114.

11. Brown G., Yule G. Discourse Analysis. Cambridge : CUP, $1983.288 \mathrm{p}$.

\section{References}

1. Gosudarstvennyye Obrazovatel'nyye Standarty Vysshego Obrazovaniya [State Educational Standards of Higher Education]. Postanovlenie Kabineta Ministrov Respubliki Uzbekistan ot 10.01.2015 g. № 3. SZ RU.2015. No. 2, st. 21. - Resolution of the Cabinet of Ministers of the Republic of Uzbekistan of 10 Jan. 2015, No. 3. SZ RU, 2015, No. 2, Article 21.

2. Polozheniye o poryadke opredeleniya urovnya znaniya inostrannogo yazyka i vydachi kvalifikatsionnogo sertifikata [Regulation on the procedure for determining the level of knowledge of a foreign language and the issuance of a qualification certificate]. Postanovlenie Kabineta Ministrov Respubliki Uzbekistan ot 31.12.2013 g. No. 352 (Prilozheniye No. 1) - Resolution of the Cabinet of Ministers of the Republic of Uzbekistan dated December 31. 2013 No. 352 (Appendix No. 1).

3. Savignon, S.J. (1997). Communicative competence: Theory and Classroom Practice. $288 \mathrm{p}$.

4. Panferova, I.V. (2015). Specific Peculiarities of Practical Teaching English Grammar at Non-Language University. European journal of education and applied psychology. Austria. No. 2. P. 58-63.

5. Riskulova, K. (2017). Sistema formirovaniya sotsiolingvisticheskoy kompetentsii budushchikh uchiteley angliyskogo yazyka [The system of formation of sociolinguistic competence of future teachers of the English language]. Doctor's thesis. Tashkent. $260 \mathrm{p}$.

6. Dmitriyenko, N.A. (2012). Formirovaniye kompetentnogo spetsialista $\mathrm{v}$ protsesse obucheniya inoyazychnomu obshcheniyu [Formation of a competent specialist in the process of teaching foreign language communication]. Molodoy uchenyy - Young scientist. No. 1. P. 83-85.

7. Morrow, K., \& Schoker, M. (1987). Using Texts in a Communicative Approach. ELT Journal. Vol. 41. No. 4. P. 248-256.

8. Jacob, G. Extensive Reading and Listening in the L2 Classroom. Retrieved from: http://www.academia.edu.

9. Moiran, S. (1990). Enseigner a comminiquer en langue etrangere. Paris, $188 \mathrm{p}$.

10. Flowerdew, L. (2002). Corpus-based Analysis in EAP: Academic Discourse. London. P. 95-114.

11. Brown, G., \& Yule, G. (1983). Discourse Analysis. Cambridge. 288 p. 
Панфьорова І.В., Томчані Л.В. Компетентнісна інтеграція мовної підготовки в процесі навчання іноземним мовам.

Анотація.

Сучасні вимоги до якості володіння мовою у випускників закладів вищої освіти зумовлюють інтеграиію нових технологій $і$ світовий досвід викладання іноземних мов. У статті розглянуто деякі актуальні питання в рамках мовної компетениії та володіння мовою. Визначено інтеграцію узбецької моделі освіти відповідно до Національної системи тестування на рівні мовної компетенції, мовної системи оцінювання та характеристик кваліфікаційних вимог. Для досягнення кінцевої мети вивчення й освоєння мови необхідно схарактеризувати зміст різних видів компетениій, що формуються в прочесі навчання іноземним мовам. У статті розглянуто головні аспекти комунікативної компетенції, лінгвістичної компетенції, соціолінгвістичної компетенції. Досліджено підходи до формування міжкультурної компетенції, компенсаторною компетенціï, дискурсивної компетениії. Виникає необхідність щодо переосмислення структури та змісту професійно-орієнтованої компетенції у сфері іноземних мов, оскільки роль і можливість викладання мови у формуванні професійних якостей фахівия в конкретному контексті його професійної діяльності не були иілком розкриті. У иьому контексті професійна компетентність випускника закладу вищої освіти має включати додаткові компоненти, що передбачають певні професійні галузі та відповідні компетенції, а також способи їх взаємодії. Таким чином, сучасна тенденція мовної підготовки з метою професійного розвитку вимагає докорінної зміни в компонентної структурі професійно-орієнтованої компетениії під час вивчення іноземних мов, модифікації навчальних матеріалів і практичної інтеграції в проиесі навчання іноземним мовам.

Ключові слова: інтеграиія; мовна підготовка; освітні стандарти; компетенції.
Панферова И.В., Томчани Л.В. Компетентностная интеграция языковой подготовки в процессе изучения иностранных языков.

Аннотация.

Современные требования к качеству владения языком у выпускников высших учебных заведений обуславливают интеграцию новых технологий и мировой опыт преподавания иностранных языков. В статье рассматриваются некоторые актуальные вопросы в рамках языковой компетенции и владения языком. Определена интеграчия узбекской модели образования в соответствии с Национальной системой тестирования на уровне языковой компетенции, языковой системой оценивания и характеристик квалификационных требований. Для достижения конечной цели изучения и освоения языка необходимо охарактеризовать содержание различных видов компетенций, формируюшихся в процессе обучения иностранным языкам. В статье рассмотрены основные аспекты коммуникативной компетенции, лингвистической и соииолингвистической компетенций. Рассмотрены подходы к формированию межкультурной компетеничи, компенсаторной компетенции, дискурсивной компетенции. Возникает необходимость переосмысления структуры и содержания профессиональноориентированной компетенции в области иностранных языков, поскольку роль и возможность преподавания языка в формировании профессиональных качеств специалиста в конкретном контексте его профессиональной деятельности не были полностью раскрыты. Профессиональная компетентность выпускника высшего учебного заведения должна включать в себя дополнительные компоненты, а также способам их взаимодействия. Современная тенденция языковой подготовки с иелью профессионального развития требует коренного изменения в компонентной структуре профессионально-ориентированной компетенции при изучении иностранных языков, модификации учебных материалов и практической интеграции в процессе обучения иностранным языкам.

Ключевые слова: интеграчия; языковая подготовка; образовательные стандарты; компетенции. 